\title{
Meta-Theoretical Framework for Executive Compensation
}

\author{
Maloa, Frans \\ Department of Industrial and Organisational Psychology, College of Management and Economic Sciences \\ University of South Africa (UNISA), PO Box 392 Pretoria 0003 \\ maloaf@unisa.ac.za
}

\section{Doi:10.5901/mjss.2014.v5n23p1686}

\section{Abstract}

This paper highlights a myriad of conceptual theoretical perspectives and their implications for executive compensation. Theoretical understanding of the determinants of executive pay is still fragmented. The lack of consensus is most visible between scholars in economics and finance, who advocate for the primacy of market-based explanations, and scholars outside of these two disciplines, who have challenged these explanations and some of their underlying assumptions by highlighting the importance of the power of social-psychological processes and the institutional environment in the creation of compensation practices. To improve the understanding of the concept and application of executive compensation, there is a need to take a closer look at the conceptualisation and theoretical perspectives that characterize the assumptions often implicit in empirical research on executive compensation. It is only through conceptualisation and a clear theoretical stance that an empirical framework can be developed. A conceptual analysis of theoretical perspectives and models is undertaken in this study. While such a conceptual framework cannot include every theory or dimension of executive compensation which is mentioned in the literature (because of the broad range of disciplines represented), it nevertheless attempts to offer a generic and integrated approach to executive compensation.

Keywords: Executive compensation, schools of thought, conceptualization

\section{Introduction}

The majority of literature on executive pay tends to overlook the (implications of) theories and the determinants derived from these theories, which not only provide theoretical explanations of executive pay, but also provide forms of legitimisation for what is actually paid in practice (cf. Gomez-Mejia and Wiseman, 1997; Wade, Porac, and Pollock, 1997; Zajac and Westphal, 1995). Given the prominence of the debate on executive compensation, both historically and currently (Van Zyl, 2010; Theunissen, 2010; Crotty \& Bonorchis, 2006), issues related to the planning of a framework for salary programmes are likely to be contentious and require extensive debate, as well as the consideration of several design alternatives (Risher, 2012). As highlighted by Lorsch and Khurana (2010), the current compensation challenges stem largely from unexamined assumptions that have fundamentally changed the nature of executive compensation and radically shifted the way in which boards, executives and even the wider' society regard the corporation and its broader purpose. Although research on CEO compensation continues to proliferate, there remains a lack of interdisciplinary consensus regarding the primary forces shaping observable patterns of executive compensation (Essen, Otten and Carberry, 2012).

The theoretical understanding of the determinants of executive pay is still fragmented (Frydman \& Jenter, 2010, p.23; Murphy, 2012, p.156). However, "Executive pay has provided fertile ground for much conceptual research originating in different disciplines and academic traditions" (Gomez-Mejia, Berronne \& Franco-Santos, 2010, p.140). The lack of consensus is most visible between scholars in economics and finance, who advocate for the primacy of marketbased explanations, and scholars outside of these two disciplines, who have challenged these explanations and some of their underlying assumptions, by highlighting the importance of the power of social-psychological processes and the institutional environment in the creation of compensation practices (Diprete, Eirich \& Pittinsky, 2010). However, schools of thought can be contradictory and complementary at the same time. This seems to be especially true for theories used in the field of executive compensation.

While most of the previous research on executive compensation uses economic perspectives such as agency theory, research that aims at examining the issue of executive compensation along the same economic theoretical tracks and using the same methodology appears to be incapable of explaining the human element as an important determinant through its social interaction, which is deeply embedded in the sociocultural and political contextual setting. As a result, 
the omission of the human element further compounds the problem of determining how to compensate executives.

To improve the understanding of the concept and application of executive compensation, there is a need to take a closer look at the conceptualisation and theoretical perspectives that characterise the assumptions often implicit in empirical research on executive compensation. It is only through conceptualisation and a clear theoretical stance that an empirical framework can be developed.

While such a conceptual framework cannot include every dimension of executive compensation which is mentioned in the literature (because of the broad range of disciplines represented), it nevertheless attempts to offer an integrated approach to executive compensation. Despite the many (fundamental) differences between the theories, the schools of thought reviewed in this paper are not necessarily contradictory, but represent different ways of examining executive compensation. One inference from these efforts is that executive pay is a very complex phenomenon that cannot be easily captured in any single model or school of thought.

This paper presents the different theoretical perspectives and highlights the ways in which they can best be viewed, in order to provide a better understanding of executive compensation. However, this paper is not specific in terms of the type of organisation, industry or sector in which the proposed framework should be applied. The intention of the current paper is to provide insight into the understanding and application of executive compensation.

Against this background, the purpose of this study is therefore to answer the following research question: How do different schools of thought contribute to the understanding and development of an executive compensation framework? More specifically, this study has two objectives:

1. To explore the input that different theoretical perspectives provide in terms of the conceptualisation and application of executive compensation.

2. To present a simplified framework for executive compensation.

Thus, this study attempts to identify different theoretical perspectives and link them to key elements of the executive compensation framework. The paper consists of three parts. The first part provides a conceptualisation of executive compensation based on the literature in this field. Thereafter, the different schools of thought will be discussed and a critical assessment will be presented. The paper concludes with a discussion on the implications for the schools of thought at individual and organisational levels.

\section{Conceptualisation of Executive Compensation}

Greckhamer (2011) defined compensation as all forms of financial returns and tangible services and benefits that employees receive as part of an employment relationship. Scholtz and Smit (2012), citing McGregor BFA, defined executive remuneration as the total cash remuneration of executive directors of a company, as disclosed in published annual reports. Typically, these end up being the top two layers within an organisation's management hierarchy (Ghose, 2011, p.9). On the one hand, cash remuneration is viewed as including the basic salary, benefits and annual bonus. Fixed compensation, on the other hand, is seen as the basis of the compensation package. Previous studies (e.g. Chen et al., 2010; Conyon and $\mathrm{He}, 2011$ ) noted that firms mainly used a cash compensation scheme, while stock options were rarely adopted. The determination of fixed compensation is usually based on competitive benchmarking, which employs a general salary survey and a detailed analysis of specific industries or market peers. However, it is usually a challenge to determine the variable pay, since it is difficult to value the stock options in the market. Therefore, this study will focus not on the determinants of either fixed or variable pay, but rather on the schools of thought that underpin executive compensation in general.

\section{Schools of Thought on Executive Compensation}

The different schools of thought that serve as a framework for executive compensation often list different factors, criteria and elements when conceptualising the determinants of executive compensation. The different schools of thought in executive compensation are discussed below.

\subsection{Cognitive theory}

Proponents of cognitive theory view the process of determining executive compensation as a psychological process or force which affects motivation and the basic needs of individual executives. According to Robbins and Judge (2011), cognitive theory is concerned with peoples' perception of their working environment and the ways in which they interpret and understand it. For those who are focusing on the cognitive aspect of executive compensation, the term 'cognition' 
has a wide meaning which goes beyond rational calculation. It denotes a broad range of mental activity, including proprioception, perception, sense- making, categorisation, inference, value judgement, and emotions. According to Robbins and Judge (2011), cognitive theory is a broad theory that includes, amongst others, theories from the psychological perspective, as well as equity (equity theory) and social comparison theory.

\subsection{Equity theory}

Boivie, Bednar and Barker (2012) posit that what is most desirable about equity theory in terms of explaining executive compensation is that equity theory has been applied at both the individual and team levels of analysis. Equity theory offers predictions about how individuals react to over-reward and under-reward situations. Gomez-Mejia et al. (2010) confirm that equity theory has played a predominant role in traditional compensation theory and practice. Equity theory, which is part of motivational theory, posits that an individual's motivation is affected by how he or she perceives the ratio of inputs (i.e. work performance) to outcomes (i.e. rewards) in relation to people who perform the same job. According to equity theory, individuals make subjective assessments of the ratio of their inputs (e.g. effort) and outcomes (e.g. compensation) to those of referent others, and experience dissonance when their perceived ratio is unequal to that of others. Gerakos, Ittner and Moers (2012) assert that employees seek to maintain equity between the inputs they provide and the outputs they receive in comparison to the perceived inputs and outputs of others (Adams, 1966; Vroom, 1964).

\subsection{Social comparison theory}

Equity theory is also related to what is known as social comparison theory. The social comparison theory expands on the equity theory through the application of social referents (Gerakos et al., 2012), which means that people usually compare themselves with those who are seen to be slightly better or more competent than themselves. In the case of setting executive pay, executives rely on normative judgments of their own pay and experience, and on judgments of the experience and pay of other executives. Boivie et al. (2012) contend that it is likely that this social comparison process of anchoring executive pay based on readily available and relevant comparison groups will help to increase executive compensation.

\subsection{Human capital theory}

Proponents of human capital theory argue against the equity theory, which states that an individual's characteristics are the most important element that determines executive compensation in an organisation. Sun, Zhao and Yang (2010) state that according to the human capital perspective, the accumulation of skills and knowledge gained through education and experience is a key element of executive compensation. Similarly, $\mathrm{Ng}$ and Feldman (2010) state that the labour market rewards individuals for acquiring more human capital with access to better jobs, higher earnings and greater incentives to stay.

Greve, Benassi and Dag Sti (2010) contend that by summing up the skills and competencies of an individual, it is possible to assess his or her level of human capital, and by calculating the skills and competencies of several workers, it is possible to estimate the level of human capital that an organisation can mobilise to meet its objectives. According to Greve et al. (2010), more education and experience enable individuals to secure a satisfactory position in the job market. The skills and experience that derive from accumulated education are therefore an asset at both individual and organisational levels.

The proponents of human capital theory seem to regard the matching of an executive's individual characteristics as an indication of an executive's ability to succeed in his or her role. The challenge, however, would be to determine how executive experience translates into pay. Feldman (2010) concludes that the positive effect of human capital on compensation is that an executive with a greater amount of human capital is better able to perform his or her job and is therefore paid more.

\subsection{Principal agency theory}

Proponents of the principal agency theory view the human capital theory as incomplete and inadequate in determining the implications of the interaction and differences in expectations between the owners of an organisation and the executive's employees. According to this theory, the agents (managers) and principals (owners) have different preferences concerning risks and effort, and this may result in manager decisions that are not optimal for the owners of 
the company (Eisenhardt, 1989; Jensen, 1983; Tosi \& Gomez-Mejia, 1989, Wiseman, Cuevas-Rodriguez, \& GomezMejia, 2012,). Thus, the owners and executives of an organisation may have differences in opinion with regard to the best interests of the organisation. Thus, executives may be seen as using organisations to get as much as they can at the expense of the owners. This may result in executives receiving as much compensation as they possibly can from the organisation.

\subsection{Managerial power theory}

Closely linked to the principal agency theory is the managerial power theory. The classical framing of the governance question surrounding executive compensation is the theory of managerialism formulated by Berle and Means (1932), which argued that managers act in their own interests, at the expense of the interests of shareholders. What seems to be important in managerial power theory is the relationship between managerial power and executive compensation within an organisation. Similarly, Ebert, Torres and Papadakis (2011) contend that managerial power theory suggests that executive compensation is a product of a variety of factors, in particular those related to the discretion and power of executive officers themselves. Chen, Ezzamel and Cai (2011) assert that the managerial power model, drawing on resource dependency theory, defines power as the ability of executives to influence pay decisions made by the board of directors or remuneration committee.

Chen et al. (2011) identify two types of executive power, namely structural power and prestige power. On the one hand, structural power is related to formal positions within an organisation and increases as executives move up the hierarchy. The greater an executive's structural power, the greater his/her control over colleagues' actions. The CEOs' structural power over internal directors enables them to pursue self-interests, including obtaining more pay. On the other hand, prestige power is related to a manager's ability to absorb uncertainty from the institutional environment, and emphasises the role of outside directorships and education as key components of prestige.

According to Chen et al. (2011), the theory makes a number of predictions regarding how the level and structure of compensation might change in the presence of certain institutional factors. Among other things, it is argued that the more power and latitude that executives exercise, the more the levels of compensation will increase, and the more pay performance sensitivity of compensation packages will decrease. This situation will be witnessed particularly when the board is relatively weak and ineffectual. Using managerial power theory, Wang, Cong and Evans $(2011$, p.3) assert that "firms with higher managerial power will be more likely to pay executives excessive compensation".

In conclusion, Van Essen, Otten and Carberry (2012) assert that managerial power theory is well equipped for predicting core compensation variables such as total cash and compensation, but less so for predicting the sensitivity of pay to performance. In most situations where CEOs are expected to have power over the pay setting process, they receive significantly higher levels of total cash and compensation. In contrast, when boards are expected to have more power, CEOs receive lower levels of total cash and compensation. In addition, powerful directors also appear to be able to establish tighter links between CEO compensation and firm performance, and can accomplish this even in the face of powerful CEOs.

\subsection{Structural theory}

Defenders of executive compensation have argued that executive compensation is a direct function of the number of organisational levels below executives. Gomez-Mejia (2010) contend that other things being equal, the taller the organisational structure, the greater the earnings of top executives. The best known rationale for this was provided by Simon (1957), who argued that "organisations attempt to maintain appropriate salary differentials between management levels and establish these differentials not in absolute terms, but as ratios" (as cited in Gomez-Mejia et al., 2010, p.134).

Gomez-Mejia et al. assert that according to the structural theory, differences between ranks are not determined by economic forces, but rather through cultural processes that create relevant norms of social stratification. In a manner somewhat akin to traditional economic models, the structural perspective is very deterministic, with the earnings of executives being mechanically established as a function of the number of levels below them and a fixed percentage difference between their pay and that of their subordinates. The resulting pay scale thus complies with cultural "norms of proportionality" between the earnings of superiors and those of subordinates.

\subsection{Contingency theory}

Contingency theory is closely related to structural theory. While the focus of structural theory is internal, contingency 
theory considers external elements such as the environment in which an organisation operates. Sun, Zhao and Yang (2010) assert that while executive compensation policies may also depend on external and internal contextual factors such as decision context, firm strategy (e.g. diversification and research and development investment), and environment (e.g. industry characteristics and national economic, cultural and political factors), the effects of contingency or contextual factors on executive compensation have generally not received adequate attention in the literature. However, Trevor (2011) states that "the outcomes of the pay determination process (practice) are contingent upon the context in which pay determination occurs, which has implications for the pay outcomes experienced as a result".

Trevor (2011, p.42) contends that if contingency theory predictions hold true, collectively speaking, the effects of the industry (as an element of the environment) might be viewed as a contextually independent variable upon which firms' pay practices, as dependent variables, are contingent. If conformity of pay practices is observed within a sample of firms - both at industry level and firm level - the standard explanation for the normative influence of the 'industry effect' is both established and powerful. It is the markets and not managers that choose the prevailing strategies within a particular environment. This clearly has a bearing on the pay trends observed within industry-level findings.

Thus, paying attention to the various political and social pressures confronting people in organisations, both internally and externally, may facilitate more effective executive compensation decision-making. Over time, employers and employees in specific contexts may build a shared history of effort-reward determination. This may involve accumulated learning with regard to how to interpret factors such as internal norms and values, as well as external indicators (e.g. comparison with other employers, as well as state legislation and trade union interventions).

\section{Overview of the Different Schools of Thought}

An overview of the different schools of thought is provided in a table form below, in order to facilitate a better understanding of these schools of thought. The table below indicates how these different schools of thought apply at different levels, which include the individual and organisational levels. The table also illustrates the impact of each theory in terms of, for example, the different criteria used to design their pay programmes. For the purposes of this study, different schools of thought are compared to each other in terms of common factors that apply when considering executive compensation. The different schools of thought are presented in a table format below for ease of comparison.

Table 1: A comparative summary of school of thoughts on executive compensation

\begin{tabular}{|c|c|c|c|c|c|c|}
\hline \multirow[b]{2}{*}{$\begin{array}{l}\text { Engagement at } \\
\text { the individual } \\
\text { level }\end{array}$} & \multicolumn{6}{|c|}{$\begin{array}{l}\text { Determinants of executive compensation (aspects that are comparable) } \\
\text { Characterised by subjectivity - challenging the fit and interaction between the individual, colleagues and } \\
\text { immediate superior } \\
\text { Common description of the schools of thought - perception of inputs and expectation of outcomes } \\
\text { School of thought }\end{array}$} \\
\hline & & & & & & \\
\hline \begin{tabular}{|l|} 
First level \\
engagement
\end{tabular} & Cognitive theory & & & & & \\
\hline $\begin{array}{l}\text { Second level } \\
\text { engagement }\end{array}$ & & $\begin{array}{l}\text { Principal } \\
\text { agency theory }\end{array}$ & $\begin{array}{l}\text { Managerial } \\
\text { power theory }\end{array}$ & & & \\
\hline \begin{tabular}{|l} 
Third level \\
engagement
\end{tabular} & & & & $\begin{array}{l}\text { Human capital } \\
\text { theory }\end{array}$ & Equity theory & $\begin{array}{l}\text { Social comparison } \\
\text { theory }\end{array}$ \\
\hline $\begin{array}{l}\text { Description of } \\
\text { perception }\end{array}$ & $\begin{array}{l}\text { Peoples' } \\
\text { perception of } \\
\text { their working } \\
\text { environment and } \\
\text { the ways in } \\
\text { which they } \\
\text { interpret and } \\
\text { understand it }\end{array}$ & $\begin{array}{l}\text { Interaction } \\
\text { and } \\
\text { differences in } \\
\text { expectations } \\
\text { between } \\
\text { owners of the } \\
\text { organisation } \\
\text { and } \\
\text { executives }\end{array}$ & $\begin{array}{l}\text { Perceptions } \\
\text { created that } \\
\text { managers act in } \\
\text { their own } \\
\text { interests at the } \\
\text { expense of the } \\
\text { interest of } \\
\text { shareholders }\end{array}$ & $\begin{array}{l}\text { Perception of } \\
\text { the importance } \\
\text { of individual } \\
\text { characteristics } \\
\text { such as } \\
\text { education, skills } \\
\text { and experience } \\
\text { for executive } \\
\text { compensation. }\end{array}$ & $\begin{array}{l}\text { Perceptions } \\
\text { created of the ratio } \\
\text { of inputs to } \\
\text { outcomes in } \\
\text { comparison to } \\
\text { people who } \\
\text { perform the same } \\
\text { job. }\end{array}$ & $\begin{array}{l}\text { Social referents with } \\
\text { which people } \\
\text { usually compare } \\
\text { themselves, i.e. } \\
\text { those who are seen } \\
\text { to be slightly better } \\
\text { or more competent } \\
\text { than themselves. }\end{array}$ \\
\hline & $\begin{array}{l}\text { Determinants of } \epsilon \\
\text { Characterised by } \\
\text { performed, in con }\end{array}$ & executive comp & pensation (aspect & larket/industry. & fthe rrapnicatis & and the jobs \\
\hline
\end{tabular}




\begin{tabular}{|l|l|l|l|}
\hline \multicolumn{2}{|l|}{ School of thought } \\
\hline $\begin{array}{l}\text { Engagement at } \\
\text { the } \\
\text { organisational } \\
\text { level }\end{array}$ & & & \\
\hline $\begin{array}{l}\text { First level } \\
\text { engagement }\end{array}$ & Structural theory & Human capital theory & \\
\hline $\begin{array}{l}\text { Second level } \\
\text { engagement }\end{array}$ & & & Contingency theory/ Institutional theory \\
\hline $\begin{array}{l}\text { Third level } \\
\text { engagement }\end{array}$ & $\begin{array}{l}\text { Executive compensation is a } \\
\text { direct function of the number of } \\
\text { organisational levels below } \\
\text { executives }\end{array}$ & $\begin{array}{l}\text { Calculating the skills and } \\
\text { competencies of several workers } \\
\text { makes it possible to estimate the } \\
\text { level of human capital that an } \\
\text { organisation can mobilise to meet } \\
\text { its objectives. }\end{array}$ & $\begin{array}{l}\text { External and internal factors such as } \\
\text { decision context (i.e. organisational } \\
\text { strategy and environment (e.g. industry } \\
\text { characteristics, cultural and political } \\
\text { executive compensation }\end{array}$ \\
\hline
\end{tabular}

Author's own compilation

Table 1 above shows the spectrum of perspectives regarding the determinants of executive compensation.

\subsection{First level of engagement}

At one end of the spectrum are those perspectives that focus on the individual level and consider executive compensation to be a subjective concept and a function of perception and expectations (cognitive theory, equity theory, and social comparison theory) between the executives themselves and what the employer can offer as compensation. The initial engagement is at the cognitive level, where the individual contemplates the compensation that is offered by the organisation or prospective employer, when he or she (the executive) first joins the organisation or is placed in or transferred to another position.

\subsection{Second level of engagement}

The second level of engagement is characterised by the level of interaction and exchange. The decision making process that occurs at the first level of engagement and the perception and expectation created are justified at the next level (principal theory). The second level is characterised by an interaction between the individual executive and the employer in terms of the exchange that takes place between what the individual can offer as an input or effort expended in delivering the service expected by the employer or potential employer. The second level of engagement is thus characterised by the level of interaction and exchange which involves the power to negotiate compensation (managerial power theory) facilitated by what the individual executive possesses (e.g. skills, experience and qualifications) (human capital theory)

\subsection{Third level of engagement}

The third level of engagement is characterised by the level of interaction and exchange, and the power to negotiate compensation (managerial power theory) at the second level is facilitated by the human capital theory, that is, in terms of what the individual executive possesses (e.g. skills, experience and qualifications).

At the other end of the spectrum are those who view executive compensation as the function of internal factors (i.e. the structure of the organisation) and the external environment. According to this perspective, executive compensation excludes claims by the individual executive and those who design, develop and implement executive compensation, since it treats an organisation as a structure outside the individual, which dictates the level of compensation that can be offered to an incumbent executive.

The difference between the individual level and the organisational level seems to suggest that executive compensation contains elements of either subjective or objective decision making with regard to executive compensation. Subjective elements seem to be initially characterised by perceptions and expectations of individuals. Objective elements, on the other hand, seem to be at the non-negotiable level, whereby factors outside the individual are selected as criteria 
for decision making regarding executive compensation. A detailed critical assessment of the schools of thought is provided in the next section.

\section{Critical Assessment of the Schools of Thought}

The different schools of thought provide substantive evidence that executive compensation is a multi-faceted concept. In order to conceptualise and better understand the issue of executive pay, and to find a way to overcome the limitations of a single dominant approach, the different schools of thought on executive compensation have demonstrated that there is no "one size fits all" approach for determining executive compensation. The different schools of thought prove that there is a need for an overview of and reference to a broader theoretical framework to be considered, in order to allow for generalisation to most compensation situations.

Given that the employment system is both an economic and psychological relationship, literature on the different schools of thought needs to be consulted in order to deepen the understanding of executive compensation. Economic theories such as the principal agency theory focus on contractual expectations and interaction between owners and executives when determining executive compensation. However, a critical assessment of the economic theories shows that the dominant use of a single theory has limitations. The principal agency theory, for example, would relate to the contractual agreements entered into between the executive and his or her employer. However, economic theories fall short in terms of the socio-psychological processes that are involved in finalising what is due to the executive in terms of pay.

Psychological theories make a contribution to the literature on social comparison and compensation. Almost all of the literature on social comparisons and equity theory attempts to determine who an individual or group is likely to refer to when making comparisons and determining whether or not their pay is equitable. Given that a selected individual or group becomes the basis for judging the equity of compensation, the choice of a specific individual or group referent is crucial.

The social comparison theory expands on the equity theory through the application of social referents (Gerakos et al., 2012), as people usually compare themselves with those who are seen to be slightly better or more competent than themselves. In the case of setting executive pay, executives rely on normative judgments of their own pay and experience, as well as on judgments of the experience and pay of other executives. Boivie et al. (2012) contend that it is likely that this social comparison process of anchoring executive pay based on readily available and relevant comparison groups will help to increase executive compensation.

However, proponents of human capital theory argue in opposition to the equity theory and the social comparison theory, by highlighting the importance of individual characteristics being considered when determining executive compensation. Sun, Zhao and Yang (2010) state that according to the human capital perspective, the accumulation of skills and knowledge gained through education and experience is a key element of executive compensation. Similarly, $\mathrm{Ng}$ and Feldman (2010) state that the labour market rewards individuals for acquiring more human capital with access to better jobs, higher earnings and greater incentives to stay. Greve, Benassi and Dag Sti (2010) contend that by summing up the skills and competencies of an individual, it is possible to assess his or her level of human capital, and by calculating the skills and competencies of several workers, it is possible to estimate the level of human capital that an organisation can mobilise to meet its objectives. The skills and experience that derive from accumulated education is therefore an asset at both individual and organisational levels, and should therefore be rewarded accordingly. The challenge, however, would be to establish how executive experience translates into pay.

Proponents of the principal agency theory view the human capital theory as incomplete and inadequate for determining the implications of the interaction and differences in expectations between the owners of the organisation and the executives' employees. According to this theory, the agents (managers) and principals (owners) have different preferences with regard to risks and effort, and this may result in manager decisions that are not in the best interests of the owners of the company. Thus, executives may be seen as using organisations to get as much as they can at the expense of the owners. This may result in the executives using the organisation to get as much compensation as possible.

Closely linked to the principal agency theory is the managerial power theory. The classical framing of the governance question surrounding executive compensation is the theory of managerialism formulated by Berle and Means (1932), which argued that managers act in their own interests at the expense of the interests of shareholders. What seems to be important in managerial power theory is the relationship between managerial power and executive compensation within an organisation. Similarly, Ebert, Torres and Papadakis (2011) contend that managerial power theory suggests that executive compensation is a product of a variety of factors, in particular those related to the 
discretion and power of executive officers themselves. Chen, Ezzamel and Cai (2011) assert that the managerial power model, drawing on resource dependency theory, defines power as the ability of executives to influence pay decisions made by the board of directors or remuneration committee.

Chen et al. (2011) identify two types of executive power, namely structural power and prestige power. On the one hand, structural power is related to formal positions within an organisation and increases as executives move up the hierarchy. The greater an executive's structural power, the greater his/her control over colleagues' actions. The CEOs' structural power over internal directors enables them to pursue self-interests, including obtaining more pay. On the other hand, prestige power is related to a manager's ability to absorb uncertainty from the institutional environment, and emphasises the role of outside directorships and education as key components of prestige.

According to Chen et al. (2011), this theory makes a number of predictions regarding how the level and structure of compensation might change in the presence of certain institutional factors. Among other things, it is argued that the more power and latitude executives exercise, the more the levels of compensation will increase, and the more pay performance sensitivity of compensation packages will decrease. This situation will be witnessed particularly when the board is relatively weak and ineffectual. Using managerial power theory, Wang, Cong and Evans (2011, p.3) assert that "firms with higher managerial power will be more likely to pay executives excessive compensation" .

In conclusion, Van Essen, Otten and Carberry (2012) assert that managerial power theory is well equipped for predicting core compensation variables such as total cash and compensation, but less so for predicting the sensitivity of pay to performance. In most situations where CEOs are expected to have power over the pay setting process, they receive significantly higher levels of total cash and compensation. In contrast, when boards are expected to have more power, CEOs receive lower levels of total cash and compensation. In addition, powerful directors also appear to be able to establish tighter links between CEO compensation and firm performance, and can accomplish this even in the face of powerful CEOs.

A more conclusive understanding of executive pay would be based on the consideration of executive pay as an outcome of socially constructed arrangements in which the executives involved have considerable discretion to influence the outcomes. Incorporating such a view in an attempt to explain executive pay provides a more conclusive explanation of the recurrent debate on executive pay in theory and practice. By helping to better understand how the process of social comparison is likely to result in increased executive compensation, the social perspective makes a number of significant contributions to the executive compensation literature. It develops the theory regarding the mechanisms through which pay increases are transmitted to the executive labour market. Unlike the economic perspective, which focuses on the dynamics of the market, the social perspective demonstrates how executive compensation is determined through an informal process of social comparison and reciprocity.

In addition, how pay increases are transmitted across firms makes a contribution to the literature on and practices of executive compensation, by showing how the socio-psychological processes related to the transfer of executive compensation result in asymmetric information transfer through network ties, which could also be better explained by economic theories. Therefore, for practical purposes, the broader theoretical framework that serves as a basis for understanding the concept of executive compensation is underpinned by different schools of thought that serve as a framework for executive compensation, which include cognitive theory, equity theory, human capital theory, principal agency theory, institutional or contingency theory and structural theory.

Defenders of executive compensation have argued that executive compensation is a direct function of the number of organisational levels below executives. Gomez-Mejia (2010) contends that other things being equal, the taller the organisational structure, the greater the earnings of top executives. The best known rationale for this was provided by Simon (1957), who argued that "organisations attempt to maintain appropriate salary differentials between management levels and establish these differentials not in absolute terms, but as ratios" (as cited in Gomez-Mejia et al., 2010, p.134).

Gomez-Mejia et al. assert that according to the structural theory, differences between ranks are not determined by economic forces, but rather through cultural processes that create relevant norms of social stratification. In a manner somewhat akin to traditional economic models, the structural perspective is very deterministic, with the earnings of executives being mechanically established as a function of the number of levels below them, and a fixed percentage difference between their pay and that of their subordinates. The resulting pay scale thus complies with cultural "norms of proportionality" between the earnings of superiors and those of subordinates.

Contingency or institutional theory is closely related to structural theory. While the focus of structural theory is internal, contingency theory considers external elements such as the environment in which an organisation operates. Sun, Zhao and Yang (2010) assert that while executive compensation policies may also depend on external and internal contextual factors such as decision context, firm strategy (e.g. diversification and research and development investment), and environment (e.g. industry characteristics and national economic, cultural and political factors), the effects of 
contingency or contextual factors on executive compensation have generally not received adequate attention in the literature. However, Trevor (2011) states that "the outcomes of the pay determination process (practice) are contingent upon the context in which pay determination occurs, which has implications for the pay outcomes experienced as a result.

Trevor (2011, p.42) contends that if contingency theory predictions hold true, collectively speaking, the effects of the industry (as an element of the environment) might be viewed as a contextually independent variable upon which firms' pay practices, as dependent variables, are contingent. If conformity of pay practices is observed within a sample of firms - both at industry level and firm level - the standard explanation for the normative influence of the 'industry effect' is both established and powerful. It is the markets and not managers that choose the prevailing strategies within a particular environment. This clearly has a bearing on the pay trends observed within industry-level findings.

If attention is paid to the various political and social pressures confronting people in organisations, both internally and externally, this may facilitate more effective executive compensation decision-making. Over time, employers and employees in specific contexts may build a shared history of effort-reward determination. This may involve accumulated learning regarding how to interpret factors such as internal norms and values, as well as external indicators (e.g. comparison with other employers, as well as state legislation and trade union interventions).

In conclusion, despite the many (fundamental) differences between the theories mentioned above, an assessment of these theories and an overview of the current state of the literature, as provided in this study, show signs of convergence in terms of theorising about executive compensation. The implications of the schools of thought at both the individual and the organisational level will be discussed in the next section.

\section{Implications for Individuals and Organisations}

In most of the executive pay literature, the fact that the (implications of) theories and the (application) determinants derived from these theories not only provide theoretical explanations of executive pay, but also provide forms of legitimisation for what is actually paid in practice (cf. Gomez-Mejia and Wiseman, 1997; Wade, Porac, and Pollock, 1997; Zajac and Westphal, 1995), is largely overlooked. Where some of the theories are rooted in economic theory and consider executive pay to be mainly determined by market forces, other theories tend to focus much more on the contextual conditions under which actual decisions on pay are made. Consequently, within the social sciences, generating better conceptualisation is a key requirement for robust research, in order to account for each determinant of executive compensation within an organisation.

\subsection{Implications of the schools of thought for individuals}

The different schools of thought have implications for individual executive compensation within an organisation. Firstly, the cognitive school of thought has demonstrated that the process of determining executive compensation is a psychological process that begins with the individual. For example, cognitive theory has shown that an individual executive will always attempt to avoid dissonance or conflict in what he or she gets as compensation and the effort spent to achieve such compensation. The executive will only be content if the effort matches the outcome in terms of compensation. That is, the higher the effort made to achieve organisational goals, the higher the compensation should be. Closely linked to the cognitive theory is the motivational or equity theory.

Equity theory in executive compensation demonstrates that an individual executive will judge the level of compensation in terms of whether or not it is fair when compared to other executives performing the same job. It seems that cognitive theory and equity theory have a common element in terms of the need to achieve fairness in what the individual believes he or she deserves compared to others, according to the input given in order to achieve organisational goals. Specifically, the different theories make a contribution by developing theory regarding the specific peer groups to which executives are likely to turn for guidance when setting executive compensation. The implications of equity theory seem to suggest that executives will participate in the exchange of justice or equity information and interrogate it by comparing their remuneration to that of people doing similar jobs.

However, the comparison between executives seems to be facilitated and informed by what an executive offers in exchange. For example, the human capital theory suggests that the human characteristics of an individual executive contribute to executive compensation. The literature that focuses on human capital as a measure of executive compensation typically finds that individual skill, level of education, age and gender, amongst other individual characteristics, account for the differences in compensation between executives. The implications of the human capital theory for executive compensation seem to suggest that the more experienced, educated and highly skilled an individual executive is, the higher his or her compensation should be. 
The principal agency theory, in relation to executive compensation, holds that executive compensation is the result of the contractual agreement between the individual and the organisation. Principal agency theory seeks to determine whether or not executive compensation is also informed by the contractual agreement, and differences in expectations between the enterprise as an employer and the executive as an employee. Principal agency theory seems to suggest that executive compensation is an instrument that is used to align the interests between shareholders and management. It is also viewed as the result of different expectations in the relationship between owners (principals) and agents (individual executives) with regard to the attainment of organisational goals. Depending on the contractual relationship, executives will demonstrate selfish tendencies to extract as much as possible from the organisation. The owners (principals) of the organisations, on the other hand, will want to extract as much as possible from the executives, in order to create shareholder value.

Closely linked to the principal agency theory and human capital theory is the managerial power theory, which asserts that executives can use their power of influence to get the compensation they want from an organisation. The implications of applying managerial power theory to executive compensation seem to suggest that executive compensation consists of what the individual possesses - for example, experience, skill and educational qualifications, which can be used in negotiations and the execution of tasks to attain organisational goals and objectives. This means that with better individual characteristics that match the organisational strategy comes better compensation.

Overall, cognitive theory, human capital theory, equity theory, and social comparison theory seem to add to the executive compensation literature, by applying a social-theoretical lens based on the ideas of social comparison, perceived inequity, and reciprocity to the arena of executive compensation.

\subsection{Implications of the schools of thought for organisations}

The different schools of thought also have implications for executive compensation at the organisational level. Firstly, the contingency theory calls for attention to be given to the environmental influences that may impact on executive compensation. Contingency theory views external elements of executive compensation such as the industry, national and political factors as the main determinants of executive compensation within an organisation. This theory suggests that how executives are compensated is a result of how the organisations would like to compare with other similar organisations in the industry. Thus, institutional or contingency theory seems to suggest that how an organisation decides to compensate its executives will be influenced by other external organisations. This means that executive compensation is a benchmarking exercise with comparable organisations. Lastly, Structural theory views executive compensation as a direct function of the number of organisational levels below executives. Structural theory will seek to establish whether or not executive compensation is also informed by the job level that the executive occupies within the organisation.

\section{Conclusion}

Executive compensation is a multi-faceted concept, and in order to conceptualise and gain a better understanding of executive pay, and to avoid the limitations of a single dominant approach, an overview of a broader theoretical framework that permits generalisation to most compensation situations is important.

This paper has demonstrated that by integrating and applying schools of thought from both the economic and socio-psychological disciplines, a better perspective and understanding of the phenomenon of executive compensation can be achieved. On the one hand, socio-psychological theories enable a more detailed description of interaction from a human and social perspective. Thus, the contributions of socio-psychological theories are mainly at the individual or micro level of analysis, which involves interaction at the individual and group level.

Economic theories, on the other hand, have contributed to the understanding of macro concepts, such as at the external environment and group level, where organisations can compare and share knowledge in relation to executive compensation. Economic theories also make it possible to understand the effects of politics and external forces such as interest groups on executive compensation. In conclusion, like theory, although different schools of thought may seem to be contradictory at first glance, they can in fact, with proper perspective and application over time, be complementary.

\section{References}

Boivie, S., Bednar, M. K., \& Barker, S. B. (2012). Social comparison and reciprocity in director compensation. Journal of Management, 0149206312460680.

Chen, J., Ezzamel, M., \& Cai, Z. (2011). Managerial power theory, tournament theory, and executive pay in China. Journal of corporate 
finance, 17(4), 1176-1199.

Crotty, A., \& Bonorchis, R. (2006). Executive pay in South Africa: Who gets what and why. Juta and Company Ltd.

Conyon, M. J., \& He, L. (2011). Executive compensation and corporate governance in China. Journal of Corporate Finance, 17(4), 11581175.

DiPrete, T. A., Eirich, G. M., \& Pittinsky, M. (2010). Compensation Benchmarking, Leapfrogs, and the Surge in Executive Pay1. American Journal of Sociology, 115(6), 1671-1712.

Eisenhardt, K. M. 1989. Agency theory: An assessment and review. Academy of Management Review, 14: 57-74.

Frydman, C. \& Jenter, D. (2010). CEO compensation. Working paper 77. Rock Centre for Corporate Governance at Stanford University. http://papers.ssrn.com/sol3/papers.cfm?abstract_id=1582232

Gerakos, J. J., Ittner, C. D., \& Moers, F. (2012). Compensation objectives and business unit pay strategy.

Greckhamer, T. (2011). Cross-cultural differences in compensation level and inequality across occupations: A set-theoretic analysis. Organization Studies, 32(1), 85-115.

Gomez-Mejia, L. R., Berrone, P., \& Franco-Santos, M. (2010). Compensation and organizational performance: Theory, research, and practice. ME Sharpe.

Gomez-Mejia., L. \& Wiseman, R. M. (1997). Reframing executive compensation: An assessment and outlook. Journal of Management, 23: 291-375.

Greve, A., Benassi, M., \& Sti, A. D. (2010). Exploring the contributions of human and social capital to productivity. International Review of Sociology-Revue Internationale de Sociologie, 20(1), 35-58.

Jensen, M. 1983. Organization theory and methodology. Accounting Review, 56: 319-338.

Lorsch, J. \& Khurana, R. (2010). The pay problem. Time for a new paradigm for executive compensation: Harvard Magazine, May/June. $30-35$.

Murphy, K. (2012). Executive Compensation: Where we are, and how we got there. Handbook of the Economics of Finance. Elsevier Science North Holland (Forthcoming).

Ng, T. W., \& Feldman, D. C. (2010). Human capital and objective indicators of career success: The mediating effects of cognitive ability and conscientiousness. Journal of Occupational and Organizational Psychology, 83(1), 207-235.

Risher, H. (2012). How Well Are Government Employees Paid?. Compensation \& Benefits Review, 44(2), 73-79.

Robbins, S. P., \& Judge, T. A. (2011). Organizational behavior (14th ed.). Upper Saddle River, NJ: Pearson.

Scholtz, H. E., \& Smit, A. (2013). Executive remuneration and company performance for South African companies listed on the Alternative Exchange (AltX). Southern African Business Review, 16(1), 22-38.

Sun, S. L., Zhao, X., \& Yang, H. (2010). Executive compensation in Asia: A critical review and outlook. Asia Pacific Journal of Management, 27(4), 775-802.

Theunissen, P. (2010). Is executive remuneration out of control. Bethlehem: Computus.

Trevor, J. (2011). Can pay be strategic?: a critical exploration of strategic pay in practice. Palgrave Macmillan.

Tosi, H. L. \& Gomez-Mejia, L. R. 1989. The decoupling of CEO pay and performance: An agency theory perspective. Administrative Science Quarterly, 34: 169-189.

Van Essen, M., Otten, J., \& Carberry, E. J. (2012). Assessing managerial power theory: A meta-analytic approach to understanding the determinants of CEO compensation. Journal of Management, 0149206311429378.

Van Zyl, G. (2010). Does employee remuneration dispersion in the South African economy enhances labour productivity? The Gauteng manufacturing industry as a case study. SA Journal of Human Resource Management/SA Tydskrif vir Menslikehulpbronbestuur, 8(1), Art. \#286, 5 pages.

Wade, J.B., Porac, J.F. \& Pollock, T.G. 1997. Worth, words and the justification of executive pay. Journal of Organizational Behavior, 18, 641-664

Wang, Q., Cong, L. M., \& Evans, J. Paper Session 3 Managerial Power and Excessive Executive Compensation.

Wiseman, R. M., Cuevas-Rodriguez, G., \& Gomez-Mejia, L. R. 2012. Toward a social theory of agency. Journal of Management

Studies, 49: 202-222.

Zajac, E. J., \& Westphal, J. D. (1995). Accounting for the explanations of CEO compensation: Substance and symbolism. Administrative Science Quarterly, 283-308. 